\title{
フロー・ショップとそのスケジュールの解析 ${ }^{\dagger}$
}

\author{
関口恭毅・小山昭一・三浦良一 \\ 北海道大学工学部 札煶市北区北 13 条西 8 丁目 \\ (昭和 46 年 12 月 6 日 受付)
}

\section{Flow Shop and Analysis of the Schedules}

\author{
Yasuki Sekiguchi, Shōichi Koyama and Ryōichi Miura \\ (Faculty of Engineering, Hokkaido University, Sapporo) \\ (Received December 6, 1971)
}

A definite description of the flow shop scheduling problems and their analytic results are presented here.

A job shop can be regarded as consisting of three kinds of components, i.e. the work station, the intermediate pool and the transport way. The reverse flow shop is defined as a shop having a flow direction opposite to that of the primal flow shop.

It makes our problems more practical and more flexible to introduce two more concepts; one is the initial condition and the other is the terminal condition. They represent the desired shapes at the beginning and at the end of the Gantt chart of the solution, respectively. Also, a generalized objective function is adopted, which can be used to estimate the idling cost of any set of work stations, the rate of operations in the shop, etc.

On the basis of these ideas, two types of deterministic scheduling problems (the Primal Problems) and their Reverse Problems (the same types of problems concerned with the reverse flow shop) are defined.

The authors are sure that the separation of the definition of shops from that of problems makes it possible to systemize various job shop problems and to utilize scheduling theory for system design.

The main results can be stated briefly as follows.

(1) A theorem which gives one of the principal methods to get the lower bounds of a class of functions including the objective function adopted.

(2) Four theorems concerned with the properties of the solutions and the structures of our generalized primal problems.

(3) Two theorems stating the mutuality of the solutions of the primal and the reverse problems.

These results would be very useful for the construction of the effective algorithms for the solution of the scheduling problems.

\section{1. 緒言}

システムの最適化問題に扔いては, たとえばプラン

下配置, 資源配分, ライン・バランシングなどのよう に最適な順列あるいは組合わせを求めることに帰着さ
れる場合が非常に多い、このような問題では，そのシ ステムの一般的記述の方法が不十分であり，かつ実用 的な組合わせ理論の応用も未発達であることが問題の 解決を困難にしていると思われる。

本論文では，最適な順列を求める問題の典型である フロー・ショップ・スケジューリングを取り上げる. 

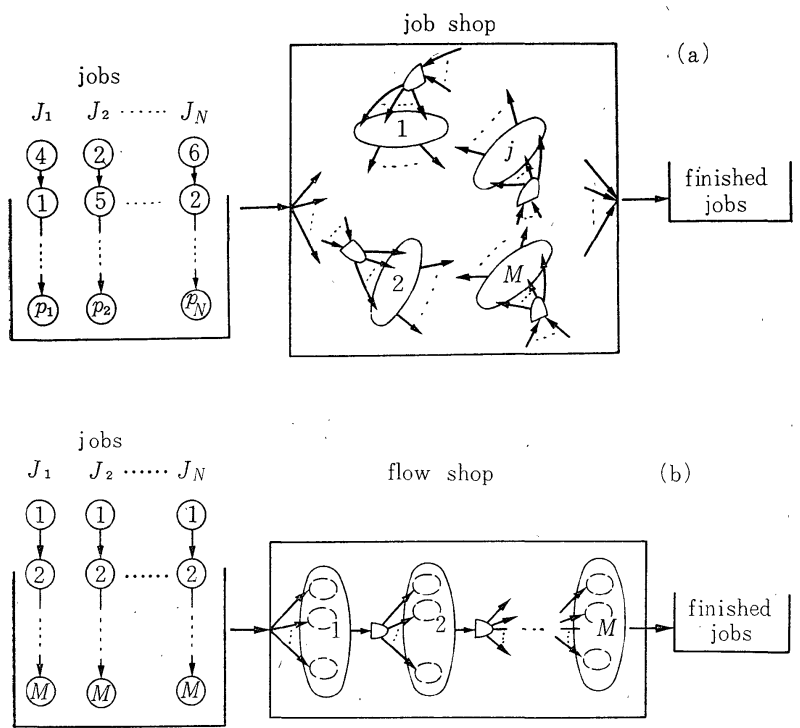

-(P)-(9)-: routing of a job, $p, q$ : index of a work stations' group $\rightarrow \mathbb{E}$ : intermediate pool, $\exists-$ :a work stations' group indexed $j$

$\longrightarrow$ :transport way

Fig. 1 A schematic representation of (a) job shop and (b) flow shop

フロー・ショップはジョブ・ショップの中で最も扱い 易いシステムであって，これに関する論文も相当多数 公表されている。しかし，これまでの研究では作業の 開始条件や仕掛量に関する設定が画一的であり，また 作業の終了条件についてはほとんど考慮されていない。 これら諸点を改善することによって, より多くの現実 の問題に適用可能な形に問題を設定できると考える.

いっぽう, 最適スケジューリングはシステムの最適 な運用を目指すものであると言えるが，とれに先立つ。 て，どのようなシステムを採用するかが問題である。

工学的な立場からすればいく種類かのシステムを比較 検討して, これを決定することが必要であって, 仕事 場としてのショップを相互に比較する合理的な方法が 望まれる. そのためには, スケジューリング問題を解 決するだけでなく, 一般的なショップの明確な記述法 を確立し，これに基ついてショップの一般的性質を解 明することが必要である. 従来のフロー・ショップ問 題の設定では仕事場であるショップとそこで処理され る仕事とを混然と記述している. 著者らは, ショップ そのものの十分な定義を与えるとともに, ここで処理 される仕事はショップと別個に規定しなければならな いと考える。

以上の観点から本論文では，2.でショップの概念を 明確にし，ショップおよび仕事に関する実用的な制約
の導入を可能にすることによって，一般的 で応用し易い形に問題を設定する．3.にお いては前章で設定した問題の一般的性能を 定理の形にまとめ，4.〜5.では留り場容量 ゼロ括よび無限大とした具体的な場合のフ ロー・ショップの性質を詳細に検討してい る.これらの諸性質は, 従来からの眼目で ある高効率の解法アルゴリズムの構成に有 益であるばかりでなく，システム相互間の 比較と最適設計への応用も考慮したより 広い視野からの解析を可能にするものであ ると考觉る. 続いて 6. では解析の諸結果 をまとめ，それに対する考察を述べる。

\section{2. 問題の設定}

\section{$2 \cdot 1$ 一般的ジョブ・ショップとフロー ショップ}

従来, ショップの一般的規定は必ずしも 明確ではない，著者らはこれを，いく種類 かの作業場（work station）と各作業場間 の運搬径路（transport way）扝よび運搬 径路の途中にある仕掛仕事の溜り場 (intermediate pool) から成ると現定するのが適当であ ると考える。このショップに与えられる仕事 (job) は いくつかの作業 (operation) から成って扬り，各作業 はその種類によって適当な作業場で処理される. ある 作業場へ作業が到着してもすぐにはその処理が開始さ れず，順番を待たねばならない場合がある。このよう な作業を格納するのが溜り場である (Fig. 1 (a)).

3 つの構成要素のとり片よってジョブ・ショップ の形態は種々に変化する. 従来普通に“ジョブ・ショ ップ”といっていたものは，上述の考方方にればシ ョップ内の各作業場がすべて異なっており，運搬径路 は任意の作業場間にあり, 溜り場の容量には制限のな いシステムであると考えることができる、フロー・シ ョップは従来処理される仕事の性質により規定されて きたが，ここでは仕事の記述とは独立にジョブ・ショ ップの中で運搬径路が特殊なるのであると考光, 次の ように定義する (Fig. 1 (b)).

【定義】(フロー・ショップ） ショップの入口か らは 1 種類の作業場へのみ運搬径路があり, 各種の作 業場は他の 1 種類の作業場または出口への運搬径路し か持たず，しかも出ロへの運搬径路は 1 種類の作業場 のみが持っているジョブ・ショップをフロー・ショッ プという・

以上はフロー・ショップの基本概念を明らかにする 
ものであるが，問題を明確に設定するにはまだ不十分 である.フロー・ショップ問題はショップの制約ばか りでなく仕事の与え方によっても種々に変化する. そ こで次の 2 節では問題を簡単化し，から厳密にするの に必要な,フフー・ショップと仕事に対する制約を述 ベる. $2 \cdot 4$ 以後で単に“フロー・ショップ”あるいは “仕事”といらときは，特の和の $2 \cdot 2$ あるいは $2 \cdot 3$ の 制約に従らものを指すものとする.

\section{2・2 フロー・ショップに関する制約}

（1）各作業場は同時に 2 個以上の作業を処理する ことはない（2）各作業に対し，それを処理できる 作業場は 1 つかない（3）考えているスケジュー ルを作業場 pが実施できるようになる時刻 $\phi^{p}$ がわか っている. $\phi^{p}(p=1,2, \cdots, M)$ はスケジュールのガン トチャートの出発点の形を決定するものであう，これ を下記のように変形し， $T_{0}$ を初期条件と呼ぶことに する。

$$
T_{0}=\left[0, \tau_{0}^{2}, \cdots, \tau_{0}^{M}\right] \text { ただし } \tau_{0}^{p}=\phi^{p}-\phi^{p-1}
$$

いっぽう，ガントチャートの終点の望むしい形を $T_{\infty}$ で示すものとする．これは $T_{\infty}=\left[\tau_{\infty}{ }^{1}, \tau_{\infty}{ }^{2}, \cdots\right.$, $\left.\tau_{\infty}{ }^{M-1}, 0\right]$ の形で与兄られるものとし, 終了条件と呼 ぶことにする.ここで $\tau_{\infty}{ }^{p}$ は作業場 $p$ が作業場 $p+1$ よりも $\tau_{\infty}^{p}$ だけ早くスケジュールを完了するのが望 ましいことを示す（4）終了条件は自由であるか, あるいは確定的に与えられる。（5）各作業場間で仕 事の運搬に要する時間は無視できる.（6）作業場は 作業不能の状態になることがなく，必要な作業員は常 に供給できるものとする。

\section{$2 \cdot 3$ 仕事と作業に関する制約}

（1）仕事は同時に2つ以上の作業場で処理される ことがない（2）仕事は処理の途中で取り消される ことなく必ず完成される。（3）同一の仕事が複数個 あってもすべて異なった種類の仕事であると考兄る.

(4) スケジュールするすべての仕事が既知で，いつ でも処理を開始できる（5）各作業の処理に要する 時間は既知で，これには準備時間も含んでおり，スケ ジュールによって変化しない（6）各作業は開始さ れたら中断されることなく完了される.（7）各作業 はそれに先行する作業がすべて完了してから開始され る.（8）各作業は先行する作業がすべて完了し，必 要な作業場が使用中でなければいらでも処理を開始さ れらる.（9）各仕事の納期は十分先であってスケジ ニーリングにさいして無視して良い。

\section{$2 \cdot 4$ 記 号}

本論文ではフロー・ショップ内の作業場に入口から
出口に向って通し番号を付し，仕事にも適当に通し番 号を付するのとする．变数にそれがどの作業場または 仕事に関するものかを示亦必要のあるときには，作業 場番号は $p, q, r$ などで示して変数の右肩に付し，仕 事の番号は $i, j, k$ などで示して変数の右下に付すの を原則とする。次に主たる記号を列記する。

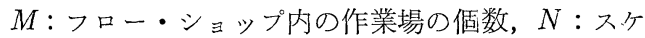
ジュールに組み入れる仕事の個数， $W^{p}$ ：入口から数 えて $p$ 番目の作業場, $\{P\}_{W},\left\{p_{1}, \cdots, p_{P}\right\}_{W}: P$ 個の作 業場の集合, $\{I\}_{J},\left\{i_{1}, \cdots, i_{I}\right\}_{J}: I$ 個の仕事の集合, $J_{i}$ : 番号 $i$ の仕事, $O(i, p): J_{i}$ の $W^{p}$ での作業, $\tau_{i}^{p}: O(i, p)$ の処理に要寸る時間, $T_{i}=\left[\tau_{i}^{1}, \tau_{i}^{2}, \cdots\right.$, $\left.\tau_{i}{ }^{M}\right]: J_{i}$ の処理所要時間, $s_{t}(i, p): \phi^{1}$ 原点にし て測った $O(i, p)$ の開始時刻, ${ }^{e} t(i, p) \equiv{ }^{s} t(i, p)+\tau_{i}{ }^{p}$ : $O(i, p)$ の終了時刻, $s^{p}: W^{p}$ で処玨する仕事の順序 (二スケジュール)， $i_{S^{p}}: W^{p}$ で $i$ 番目に処理される仕 事の番号, $s\{M \times N\}:$ ショップ全体のスケジュール. 第 $p$ 行が $s^{p}$ である $M \times N$ のマトリクス, $\beta=\left[\beta^{2}\right.$, $\left.\beta^{3}, \cdots, \beta^{M}\right]: \beta^{p}$ は $W^{p-1}$ と $W^{p}$ の間にある溜り場の 容量であって, そこに格納できる最太の仕事個数を示 す, $S$ : 任意のフロー・ショップ，作業場数や溜り場 容量を明示する必要のあるときは, $\boldsymbol{S}(M), \boldsymbol{S}(M, \boldsymbol{\beta})$ などと記す， $\boldsymbol{S}_{\mathrm{I}}$ ：すべてのpに対し， $\beta^{p}=+\infty$ であ る $\boldsymbol{S}, \boldsymbol{S}_{\text {II }}$ : すべての $p$ に対し, $\beta^{p}=0$ である $\boldsymbol{S}$.

$\boldsymbol{S}$ で処理されるすべての仕事の技術的順序 $R$ は同じ でなければならないから，特にこれを示す必要はなく。 各仕事は処理所要時間 $T_{i}$ を与えれば確定する。 $T_{i}$ は 初期条件 $T_{0}$, 終了条件 $T_{\infty}$ と同じ形式であるから, $T_{0}$ と $T_{\infty}$ は扮の扔の常にスケジュールの最初または 最後に処理される仕事 $J_{0}$ および $J_{\infty}$ と解釈すること もできる.この場合 $J_{0}$ の開始掞よび終了の時刻は次 のように与えられる。

$$
{ }^{s} t(0,1)=0,{ }^{s} t(0, p)=\sum_{q=1}^{p-1} \tau_{0}^{q},{ }^{e} t(0, p)={ }^{s} t(0, p)+\tau_{v}{ }^{p}
$$

したがって ${ }^{s} t(0, p)={ }^{e} t(0, p-1)$ である. $J_{\infty}$ につい ても ${ }^{s} t(\infty, p),{ }^{e} t(\infty, p)$ を考えることができるが， $J_{0}$ のときと異なりスケジュールによって変化する. しかし， $T_{\infty}$ はスケジュール終了時のガントチャート の形を規定するものであって, ${ }^{s} t(\infty, p)={ }^{e} t(\infty, p-1)$ なる関係は満たさなければならない。なお， ${ }^{e} t(\infty, p)$ $\equiv{ }^{s} t(\infty, p)+\tau_{\infty}^{p}$ とする.

\section{$2 \cdot 5$. 目的関数}

フロー・ショップにおけるスケジニールの評価とし ては, 総所要時間 (total required time) がよく用い られるが，これを最小にすることは，最後の作業場 $W^{M}$ の遊び時間を最小にすることと等価である。こ 
こではこれを一般化した総遊び費用 C (total idling cost of $S)$ をを用いる.

$$
\begin{aligned}
C & \left(\boldsymbol{S}, s\{M \times N\}, T_{0}, T_{\infty} ; \boldsymbol{\alpha}\right) \\
& =\sum_{p=1}^{M}\left[\alpha^{p} \cdot\left\{\sum_{c} I_{i}^{p}\left(\boldsymbol{S}, s\{M \times N\}, T_{0}, T_{\infty}\right)\right\}\right]
\end{aligned}
$$

上式で $\alpha=\left[\alpha^{1}, \alpha^{2}, \cdots, \alpha^{M}\right]$ であり $\alpha^{p}$ は $W^{p}$ の単 位遊び時間当たりの重みである. $I_{i}^{p}(\cdot, \cdot, \cdot)$ は $S$ で $s\{M \times N\}$ を $T_{0}, T_{\infty}$ の下で実行するとき $O\left(i_{s^{p}}, p\right)$ の処理開始直前の $W^{p}$ の単位遊び時間である. 以下 では $I^{p}\left(S, s\{M \times N\}, T_{0}, T_{\infty}\right)$ で $I_{i}^{p}$ の $i$ 関す る総和を示す.この $i$ に関する和は $T_{\infty}$ : 自由のとき は $N$ まで， $T_{\infty}$ が確定的に与えられているときは, 終了条件玉でとる、な怔， $T_{\infty}$ ：自由のときは上式の （）の中の $T_{\infty}$ を省き, 特に混乱のおそれがないと きは $\left(\boldsymbol{S}, s\{\}, T_{0}, T_{\infty}\right)$ そのものを省略することもあ る.Cの引数としてSがはいっているのは, 同じスケ ジュールであってもそれを実行するフロー・ショップ によってCが変化するからである.

$C$ は $\alpha^{p}$ を $W^{p}$ の単位遊び時間当たりの費用にと れば総遊び費用となり， $\alpha^{p}=0$ for $p=1,2, \cdots, M-1$, $\alpha^{M}=1$ とすれば $W^{M}$ の総遊び時間となって, 総所要 時間と同等になる.またすべてのpに対して $\alpha^{p}$ を 1 にすると，Cを最小にすることはショップの稼動率を 最大にすることと等価になる．このように $\boldsymbol{\alpha}$ の与え方 で（2）式に種々の物理的意味を持たせることができ， ショップに注目した評価を考えるさいには非常にはん 用性がある。しかし，たと光ば各仕事の完了時刻と納 期の差を少なくしようといらような仕事奇りの評価を 行ならには不向さであると思われる。

ここで（2）式をその特殊形として含む，より一般 的な関数 $F$ の性質を示す。これは (2) 式の下界の推 定に有効である.

【定理 $1 】$ 関数 $F$ が下の $(3)$, (4) 両式を満た

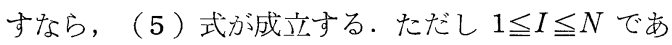
る.

$$
\begin{aligned}
& F\left(\boldsymbol{S}(M), s\{M \times N\}, T_{0}, T_{\infty}\right) \\
& \quad=\sum_{p=1}^{M} F^{p}\left(\boldsymbol{S}(M), s\{M \times N\}, T_{0}, T_{\infty}\right) \\
& =F\left(\boldsymbol{S}(M), s_{I}, T_{0}, T_{0 I}\right)+F\left(\boldsymbol{S}(M), s_{N-I}, T_{0 I}, T_{\infty}\right) \\
& F\left(\boldsymbol{S}(M), s\{M \times N\}, T_{0}, T_{\infty}\right) \\
& \quad \geqq F\left(\boldsymbol{S}(M), s_{I}, T_{0}, T_{0 I}\right) \\
& \quad+\sum_{p=1}^{M} F^{p}\left(\boldsymbol{S}\left(m^{p}\right), s^{*}\left\{m^{p} \times(N-I)\right\}, T_{0 I}{ }^{p}, T_{\infty}^{p}\right)
\end{aligned}
$$

ここで $s_{I}, s_{N-I}$ は $s\{M \times N\}$ の $I$ 列目までとそれ 以後を扮の打の示す. $T_{0 I}=\left[0, \tau_{0 I}{ }^{2}, \cdots, \tau_{0 I}{ }^{M}\right]$ は $s_{I}$
の終了時刻から算出する $s_{N-I}$ の初期条件である. $s^{*}$ $\left\{m^{p} \times(N-I)\right\}$ は $W^{p}$ を含む $m^{p}$ 個の作業場 $(2 \leqq$ $\left.m^{p} \leqq M\right)\{p-q+1, \cdots, p-1, p, p+1, \cdots, p+r\}_{W}$ の みを考虑し, 評価として $F$ の $W^{p}$ 海関する部分 $F^{p}$ のみを考えたときの $T_{0 I}{ }^{p}, T_{\infty}^{p}$ の下で最適な $N-I$ 個の仕事のスケジュールである.

ただし， $T_{0 I}{ }^{p}=\left[0, \tau_{0 I}^{p-q+2}, \cdots, \tau_{0 I}^{p+r}\right]$,

$$
T_{\infty}{ }^{p}=\left[\tau_{\infty}{ }^{p-q+1}, \cdots, \tau_{\infty}{ }^{p+r-1}, 0\right]
$$

【証明】あるスケジュール $s^{\prime}\{M \times N\}$ について あるIで（5）式が成立しないとする。（3），(4) 式 加,

$$
\begin{gathered}
F\left(\boldsymbol{S}(M), s^{\prime}\{M \times N\}, T_{0}, T_{\infty}\right)=F\left(\boldsymbol{S}(M), s_{I}{ }^{\prime}, T_{0}, T_{0 I}\right) \\
\quad+\sum_{p=1}^{M} F^{p}\left(\boldsymbol{S}(M), s_{N-I^{\prime}}, T_{0 I}, T_{\infty}\right)
\end{gathered}
$$

いっぽう，仮定から，

$$
\begin{gathered}
F\left(\boldsymbol{S}(M), s^{\prime}\{M \times N\}, T_{0}, T_{\infty}\right)<F\left(\boldsymbol{S}(M), s_{I^{\prime}}, T_{0}, T_{0 I}\right) \\
\quad+\sum_{p=1}^{M} F^{p}\left(\boldsymbol{S}\left(m^{p}\right), s^{*}\left\{m^{p} \times(N-I)\right\}, T_{0 I}{ }^{p}, T_{\infty}{ }^{p}\right)
\end{gathered}
$$

（6）式と（7）、式を比較すると少なくとも1つの $p$ $(1 \leq p \leq M)$ について次式が成立しなければならない。 $F^{p}\left(\boldsymbol{S}(M), s_{N-I^{\prime}}, T_{0 I}, T_{\infty}\right)$

$$
<F^{p}\left(\boldsymbol{S}\left(m^{p}\right), s^{*}\left\{m^{p} \times(N-I)\right\}, T_{0 I^{q}}, T_{\infty}^{p}\right)
$$

このことは $m^{p}$ の值が何であうても $s^{*}$ の定義に矛盾 する。したがって背理法により（5）式がずてのス ケジュールについて成立しなければならない（証明 終)

\section{$2 \cdot 6$ 本論文で扱う問題の記述 (Fig. 2)}

本論文では, $\mathrm{P} 1(\boldsymbol{S}, \boldsymbol{\alpha})=\left\{\boldsymbol{S} ; T_{0}, T_{\infty} ;\{N\}_{J} ; \boldsymbol{\alpha}\right\}, \mathrm{P} 2$ $(\boldsymbol{S}, \boldsymbol{\alpha})=\left\{\boldsymbol{S} ; T_{0} ;\{N\}_{J} ; \boldsymbol{\alpha}\right\}$ なる問題を扱う. $\mathrm{P} 1(\boldsymbol{S}, \boldsymbol{\alpha})$ は $\mathbf{2} \cdot \mathbf{2}$ の制約に従らフロー・ショップに $\mathbf{2 \cdot 3}$ の制約 を満たす $N$ 個の仕事が与兄られたとき， $T_{0}, T_{\infty}, \boldsymbol{\alpha} の$ 下で目的関数（2）を最小にする問題であり，P2(S, a) はその $T_{\infty}$ が自由の場合である.これは（2）式 の $i$ に関する和が $N$ までである点のみが $\mathrm{P} 1$ と異な っている. 以上の 2 つを原問題といい, これに対応す る逆順序問題を次のように定義する。

$$
\begin{aligned}
& \mathrm{P} 1(\overline{\boldsymbol{S}}, \overline{\boldsymbol{\alpha}})=\left\{\overline{\boldsymbol{S}} ; \bar{T}_{0}, \bar{T}_{\infty} ;\{N\}_{J} ; \overline{\boldsymbol{\alpha}}\right\} \\
& \mathrm{P} 2(\overline{\boldsymbol{S}}, \overline{\boldsymbol{\alpha}})=\left\{\overline{\boldsymbol{S}} ; \bar{T}_{0} ;\{N\}_{J} ; \overline{\boldsymbol{\alpha}}\right\}
\end{aligned}
$$

ここで $\overline{\boldsymbol{S}}$ は作業場の配列が $\boldsymbol{S}$ と逆の順序のものであり。 $\bar{\alpha}=\left[\bar{\alpha}^{M}, \cdots, \bar{\alpha}^{2}, \bar{\alpha}^{1}\right]=\left[\alpha^{1}, \alpha^{2}, \cdots, \alpha^{M}\right]$ で $\bar{\alpha}^{p}$ は $W^{p}$ に対する $\overline{\boldsymbol{S}}$ での重みである， $\overline{\boldsymbol{S}}$ に対する仕事であるか. ら $J_{i}$ は $\bar{T}_{i}=\left[\tau_{i}^{M}, \tau_{i}^{M-1}, \cdots, \tau_{i}^{1}\right]$ の形となる.（8) では $\bar{T}_{0}=\left[0, \tau_{\infty}{ }^{M-1}, \cdots, \tau_{\infty}{ }^{1}\right], \bar{T}_{\infty}=\left[\tau_{0}{ }^{M}, \tau_{0}{ }^{M-1}, \cdots\right.$, $\left.\tau_{0}^{2}, 0\right]$ であり, (9) では $\bar{T}_{0}=\left[0, \tau_{0}^{2}, \cdots, \tau_{0}{ }^{M}\right]$ とす る.な打（8）と同様に（9）でも $\bar{T}_{0}$ : 自由, $\bar{T}_{\infty}=$ 
minimize eq. (2) for $\alpha, T_{0},\left(T_{\infty}\right)$

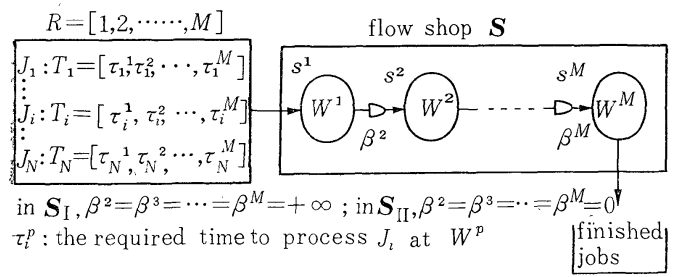

(a) the primal problem

minimize eq. (2) for $\bar{\alpha}, \bar{T}_{0},\left(\bar{T}_{\infty}\right)$

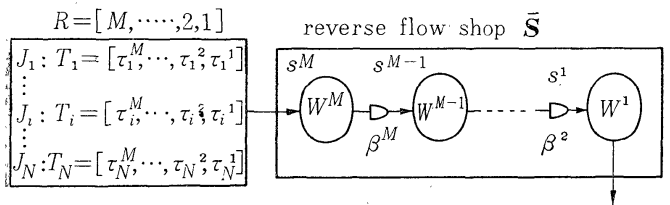

for P1, $\bar{T}_{0}=\left[0, \tau_{\infty}^{M-1}, \cdots \cdots, \tau_{\infty}^{1}\right] ; \bar{T}_{\infty}=\left[\tau_{0}^{M}, \cdots \cdots, \tau_{0}^{2}, 0\right]$ finished for $\mathrm{P} 2, \bar{T}_{0}=\left[0, \tau_{0}^{2} \cdots \cdots \tau_{0}^{M}\right] ; \bar{T}_{\infty}:$ free

(b) the reverse problem

Fig. 2 Schematic representations of the primal and reverse problems

$\left[\tau_{0}{ }^{M}, \cdots, \tau_{0}{ }^{2}, 0\right]$ とするとこれは（8）とまったく同 じに扱完ることがわかっている。

著者らは問題の設定にさいし， $S$ に刘して溜り場の 容量制限，初期条件；終了条件を新に導入した。これ らは従来の研究ではほとんど考慮されていないが，現 実のショップを考觉るととらぜんモデルに導入すべき

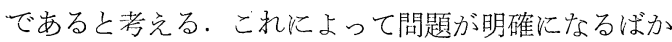
りでなく，ある意味で問題が単純化されることが以下 の解析で明らかになる。さらにたと壳ば，原 ${ }^{3)}$ の $\mathrm{Cy}$ clic Sequencing の問題をいくつかの P1 の集合に変 形することによってより良い近似解が得られるよりに もできる，逆順序問題の正確な定義および解析は従来 汪とんど見られないが，この問題の意義については 6. で述べる.

\section{3. フロー・ショップ全般の性質}

ジョブ・ショップの最適スケジュールの決定には仕 事のたかだか $(N !)^{M}$ 個の順列を探策すれば良いこと がわかっている2゙.フロー・ショップではこれを $(N !)^{M-2}$ 個まで減らして良い*1.

【定理 2】(Johnson-Roy の定理) $\mathrm{P} 1(\boldsymbol{S}, \boldsymbol{\alpha})$ 拧 よび P $2(\boldsymbol{S}, \boldsymbol{\alpha})$ では評価を悪化させずに $s^{1}=s^{2}, s^{M-1}$

*1 P2 $\left(S_{I},[0,0, \cdots, 0,1]\right)$ 飞関するこの性質は文献 4) p. 91 に引用されているが，その詳細については触られ ていない，原典は文献 5) であるが入手しにくい。こ こでは筆者ら独自の命題とその証明を述べる。また， 文献1) では P2 $\left(S_{\mathrm{I}}(3),[0,0,1]\right)$ 亿関してこの性質 が証明されている。
$=s^{M}$ とできる.

【証明】 Fig. 3 参照. $s^{M-1}$ と $s^{M}$ を最初から対 照して行くと, $k$ 番目で初めて $k_{S M-1} \neq k_{S M}$ であって, $k_{S M-1}=k+l_{S M}, k_{S M}=k+j_{S M-1}$ であるとする. $J_{k+l_{S M} \rightarrow}$ $J_{k \widetilde{M}}, J_{i_{S M}} \rightarrow J_{i+1} \widetilde{M}(k \leq i \leq k+l-1)$ 之置き換えたス ケジュール $\tilde{s}^{M}$ (他の部分は $s^{M}$ 之同じ) を作る.

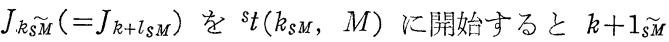
から $k+l_{s \widetilde{M}}$ までの仕事は $s^{M}$ のときと同时刻かある いは直前の仕事が終了した時刻に処理開始できるので, $k+l_{S \widetilde{M}}$ は $k+l_{S M}$ 之同じ時刻に終了できる.これで評 価を悪化させずに できた．この操作の繰返しによって $s^{M-1}=s^{M}$ とでき る. $s^{1} \neq s^{2}$ のとさは $s^{1}$ の汇うを上と同様にして変更 していけば良い*2。なお，この証明では $2 \cdot 3$ の制約 （3）を使っていないので仕事はこれを満たしてなく とも良い。

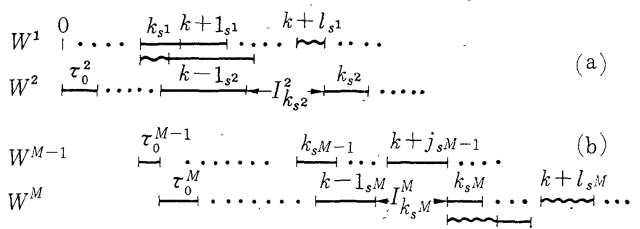

Fig. 3 Partial Gantt chart of schedule $s$

上の定理により， $M \leqq 3$ の $S$ では $N$ ! 個の順列だ けを考慮すれば良いことがわかる。市た $s^{p} キ s^{q}$ ，とな るのは溜り場の容量がすべてゼロのときは不可能であ るから $\boldsymbol{S}_{\text {II }}$ では $s^{1}=s^{2}=\cdots=s^{M}$ でなければならない 次の定理は $T_{\infty}$ を与兄られた問題では評洒関数の重 み拜たとえばアルゴリズムに都合良いように決めて 良いことを示している。

【定理 3】 $\mathrm{P} 1(\boldsymbol{S}, \boldsymbol{\alpha})$ では解集合 $\left\{s^{*}\right\}$ ほ， $\boldsymbol{\alpha} の$ 值の変化には敏関係に一定である。ただし， $\boldsymbol{\alpha \neq 0}$.

【証明】 $\alpha^{M}=1$ で他の $\alpha^{p}$ はすべてゼロのとき の最適スケジュールを $s^{*}$ で，その集合を $\left\{s^{*}\right\}$ で示 す.この $s^{*}$ に対する簡単なガントチャートを Fig. 4 に示す. $D_{s^{*}}{ }^{p}{ }^{s} t(\infty, p)-{ }^{e} t(0, p)$ であり，初期条件と 終了条件の定義加 ${ }^{e} t(0, p)={ }^{s} t(0, p+1),{ }^{e} t(\infty, p)=$ $s_{t}(\infty, p+1)$ でなければならない. $s^{*} の$ 定義から $D_{S^{*}}{ }^{M}$ は実現可能な最小值である. $q(1 \leq q \leq M-1)$ に

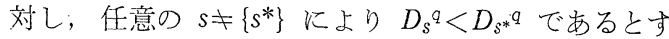
ると，上述の $T_{0}$ 之 $T_{\infty}$ の性質から $D_{s}{ }^{M}<D_{S^{*}}{ }^{M}$ でな ければならず，矛盾を生ずる。したがって $D_{S^{*}}{ }^{q}(1 \leq q$

*2 $S_{\mathrm{I}}$ だけを考光る時は $s^{1}=s^{2}$ とできることの証明は， $s^{M-1}=s^{M}$ とできることの証明より容易でより一般的 な評価についてできるが；一般の $S$ を考虑するときは そのような差はなくなる。 


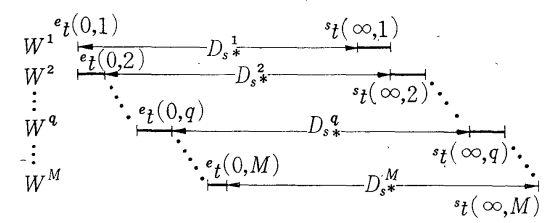

constr. ${ }^{e} t(0, q)={ }^{s} t(0, q+1),{ }^{e} t(\infty, q)={ }^{s} t(\infty, q+1)$

Fig. 4 The span $D_{s} *^{q}$ from $T_{0}$ to $T_{\infty}$

$\leq M-1 ）$ も実現可能な最小值でなけ礼ばならない。 ゆ克に任意の $\boldsymbol{\alpha}$ 亿対して $\left\{s^{*}\right\}$ は最適スケジュールの 集合であり，\{s*\} に含を机ないスケジュールは $\boldsymbol{\alpha} の$ 値がなんであっても最適にはなり得ない。

\section{I 形と II 形のフロー・ショップの性質}

\section{1 $M=2$ の I 形フロー・ショップの性質}

Johnson は P2 $\left(\boldsymbol{S}_{\mathrm{I}}(2),[0,1]\right) て ゙ T_{0}=[0,0]$ の場 合に最適スケジュールとなる十分条件を導き，それを 満たすスケジュールを作るアルゴリズムを与光だ1). ここでは同じ条件式が任意の P1 $\left(\boldsymbol{S}_{\mathrm{I}}(2), \boldsymbol{\alpha}\right)$ および $\mathrm{P} 2\left(\boldsymbol{S}_{\mathrm{I}}(2), \boldsymbol{\alpha}\right)$ に対して最適性の十分条件となること を示す。

【定理 4】 $\mathrm{P} 1\left(\boldsymbol{S}_{\mathrm{I}}(2), \boldsymbol{\alpha}\right), \mathrm{P} 2\left(\boldsymbol{S}_{\mathrm{I}}(2), \boldsymbol{\alpha}\right)$ では (10) 式の成立することが最適スケジュールであるた めの十分条件である，ただし，(10) 式は $1 \leq j \leq N-1$ なるすべてのうについて成立しなければならない。

$$
\min \left(\tau_{j_{s}}{ }^{1}, \tau_{j+1_{s}}{ }^{2}\right) \leqq \min \left(\tau_{j_{s}}{ }^{2}, \tau_{j+1_{s}}{ }^{1}\right)
$$

【証明】 $\mathrm{P} 2\left(\boldsymbol{S}_{\mathrm{I}}(2), \boldsymbol{\alpha}\right)$ では $W^{1}$ の遊び時間 $I^{1}$ は常にゼ口沉できるから， $I^{2}$ の最小化だけを考光机 ば良い。このとき $I^{2} は$ は (11)，(12）式によって与光 られる。

$$
\begin{gathered}
\left.I^{2}=\underset{1 \leq u \leq N}{\max \{\max } K_{u}(s), \tau_{0}{ }^{2}\right\}-\tau_{0}{ }^{2} \\
K_{u}(s)=\sum_{j=1}^{u} \tau_{j_{s}}{ }^{1}-\sum_{j=1}^{u-1} \tau_{j_{s}}{ }^{2}
\end{gathered}
$$

したがって, $\max K_{u}(s)$ を最小化すれば $I^{2}$ は最小 值になる。つまり Johnson の条件が十分条件である。

$\mathrm{P} 1\left(\boldsymbol{S}_{\mathrm{I}}(2), \boldsymbol{\alpha}\right)$ では $I^{2}$ は次のように書ける。

$$
I^{2}=\max \left\{\sum_{j=1}^{N}\left(\tau_{j}^{1}-\tau_{j}{ }^{2}\right)+\tau_{\infty}{ }^{1} \max _{1 \leq u \leq N} K_{u}(s), \tau_{0}{ }^{2}\right\}-\tau_{0}{ }^{2}
$$

\{·\}の中の第 1 項は定数であるからやはり，Johnson の条件が満たされれば $I^{2}$ は最小になる。したがって $\boldsymbol{\alpha}=[0,1]$ なら最適性の十分条件淿なる。これ之定理 3を用い机ば任意の $\boldsymbol{\alpha}$ 亿対して, Johnson の条件が 十分条件となることがわかる。

(10) 式の関係が推移的であることから，定理 4 を 用いて容易に次の 2 つ系を証明できる.
【系 4-1】 $\mathrm{P} 1\left(\boldsymbol{S}_{\mathrm{I}}(2), \boldsymbol{\alpha}\right)$ あるいは $\mathrm{P} 2\left(\boldsymbol{S}_{\mathrm{I}}(2), \boldsymbol{\alpha}\right)$ の (10) 式を満たす解を $s^{*}\{2 \times N\}$ とするとき， $\{N\}_{J}$ から $\{n\}_{J}=\left\{J_{i_{1 s^{*}}}, J_{i_{2 S^{*}}}, \cdots, J_{i_{n S^{*}}}\right\}_{J}\left(i_{k}<i_{k+1}\right.$ とする $)$ を除いた $\{N-n\}_{J}$ に対する同じ問題の解は（14）で ある。

$$
\begin{aligned}
s^{*} & \{2 \times(N-n)\} \\
\quad & =\left[1_{s^{*}}, \cdots, i_{1}-1_{s^{*}}, i_{1}+1_{s^{*}}, \cdots, i_{n}-1_{s^{*}}, i_{n}+1_{s^{*}}, \cdots\right]
\end{aligned}
$$

【系 4-2】 $\mathrm{P} 1\left(\boldsymbol{S}_{\mathrm{I}}(2), \boldsymbol{\alpha}\right)$ あるいは $\mathrm{P} 2\left(\boldsymbol{S}_{\mathrm{I}}(2), \boldsymbol{\alpha}\right)$ の（10）式を満たす解を $s^{*}\{2 \times N\}$ とするとき， $J_{N+1}$ を加光た $\{N+1\}_{J}$ 飞対する同じ問題の解は， $s *$ の次 式が成立する位置に $J_{N+1}$ を割込ませたものである。 な技，（15）が $j=N$ で成立するときは $s^{*}$ の最後に， (16) が $j=0$ 亿対して成立するときは $s^{*}$ の先頭に, おの扮の $J_{N+1}$ を割达ませるものとする。

$$
\begin{aligned}
& \min \left(\tau_{j_{s^{*}}}{ }^{1} \tau_{N+1}{ }^{2}\right)<\min \left(\tau_{j s^{*}}{ }^{2}, \tau_{N+1}{ }^{1}\right) \\
& \min \left(\tau_{j+1 s^{*}}, \tau_{N+1}\right) \leqq \min \left(\tau_{j+: s^{*}}, \tau_{N+1^{2}}\right)
\end{aligned}
$$

【系 4-1】はスケジュール実行中に仕事の取り消し があった場合や，Branch and Bound 法を用いるさ いの下界の推定などに利用できる、【亲 4-2】はJohn一 son の方法とは異なる最適スケジュールの構成法を示 すとともに，仕事の割込みがあった場合にも有效であ る.

\section{2 $M=2$ の II 形フロー・ショップの性質}

【定理 5】 $\mathrm{P} 1\left(\boldsymbol{S}_{\mathrm{II}}(2), \boldsymbol{\alpha}\right), \mathrm{P} 2\left(\boldsymbol{S}_{\mathrm{II}}(2), \boldsymbol{\alpha}\right)$ では下 の 3 つのちのぞれを仮定してスケジュールsの評価 を計算しても同じ值を得る。

$$
\begin{aligned}
& { }^{e} t\left(j-1_{s}, 2\right)={ }^{s} t\left(j+1_{s}, 1\right) \\
& { }^{s} t\left(j+1_{s}, 1\right)={ }^{s} t\left(j_{s}, 2\right) \\
& { }^{s} t\left(j_{s}, 2\right)={ }^{e} t\left(j_{s}, 1\right)
\end{aligned}
$$

【証明】 $\boldsymbol{S}_{\text {II }}$ では $W^{1}$ と $W^{2}$ の間に仕事が溜る ことを許さないから， $M=2$ の場合は $W^{1}$ が $J_{j+1 s}$ を 開始するには，W1 が $J_{j_{s}}$ を $W^{2}$ が $J_{j-1 s}$ を特の打 の完了していることが必要である、いっぽら，W2が

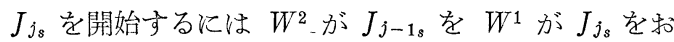
の扔の完了していることが必要である.よって $W^{1}$ む $W^{2}$ もできるだけ早く仕事を開始するものとすると (20) 式が成立する.

$$
\begin{aligned}
& s_{t}\left(j+1_{s}, 1\right)={ }^{s} t\left(j_{s}, 2\right) \\
& \quad=\max \left\{e t\left(j_{s}, 1\right),{ }^{e} t\left(j-1_{s}, 2\right)\right\}
\end{aligned}
$$

(1) $e_{t}\left(j_{s}, 1\right) \geqq^{e t}\left(j-1_{s}, 2\right)$ のとき：(20) 武加 $s_{t}\left(j_{s}, 2\right)={ }^{e} t\left(j_{s}, 1\right)$ (Fig. 5(b)).

(2) ${ }^{e t}\left(j_{s}, 1\right)<{ }^{e t}\left(j-1_{s}, 2\right)$ のとき:Fig. 5 (a) のよ゙うになり, $J_{j_{s}}$ の $W^{1}$ での開始を ${ }^{e t}\left(j-1_{s}, 2\right)-$ ${ }^{e} t\left(j_{s}, 1\right)$ だ忙遅らせて ${ }^{s} t\left(j_{s}, 2\right)={ }^{e t}\left(j_{s}, 1\right)$ としても $I_{j+1}{ }^{1}$ が $I_{j}{ }^{1}$ のところにはいるだけで評価は悪化しな 


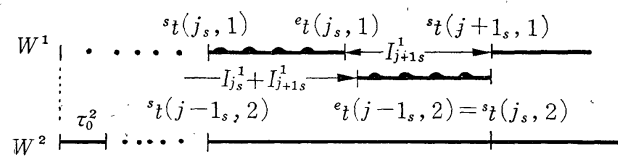

(a) ${ }^{e} t\left(j_{s}, 1\right)<{ }^{e} t\left(j-1_{s}, 2\right)$

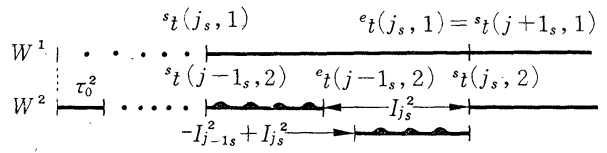

(b) ${ }^{e} t\left(j_{s}, 1\right) \geqq{ }^{e} t\left(j-1_{s}, 2\right)$

Fig. 5 Relations between the starting and the ending time of operations in $S_{\text {II }}$ (2)

W.

同様にして (1)，(2) の場合とも $s^{s} t\left(j+1_{s}, 1\right)={ }^{e} t(j$ - $\left.1_{s}, 2\right)$ ともできることが容易にわかる.

(17) は $W^{2}$ での開始特刻を，(19）は $W^{1}$ での開 始時刻を，（18）の場合より評価が悪化しないように できるだけ遅らせる場合に相当する．特に（19）の場 合を利用すると $S_{\mathrm{II}}(2)$ でのスケジューリング問題が 巡回セールスマン問題の変形となる。このことから $M \geqq 3$ の場合でも $M$ があまり大きくなければ，巡回 セールスマン問題の解法を利用して $S_{\text {II }}$ に対するかな り良い近似解が得られるものと推測される。

\section{5. 原問題ट逆順序問題の解の関係}

【定理 6】 $\mathrm{P} 1(\boldsymbol{S}, \boldsymbol{\alpha})$ のスケジュール $s$ が時刻. ${ }^{s} t$ ( $\left.j_{s}, p\right)$ に $O\left(j_{s}, p\right)$ を開始するものであるとき, $\bar{s}$ は 各作業を次の (21) 式で決まる時刻に開始すれば, そ の逆順序問題のショップ $\overline{\boldsymbol{S}}$ で常に実施できる.

$s_{t} t\left(j_{\bar{s}}, p\right)={ }^{s} t(\infty, M)-{ }^{e} t\left(N-j+1_{s}, p\right)$

【証明】 $S$ ではあるスケジュール $s$ が実行される とき，作業を行なら時刻について（22）式が成立しな 讨ればならない。

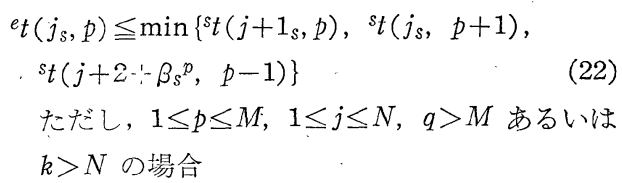

$$
s_{t}\left(k_{s}, q\right) \equiv+\infty
$$

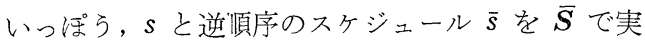
行できるための条件は（23）式となる。

$$
\begin{aligned}
& s_{t}\left(j_{\bar{s}}^{-}, p\right) \geqq \max \left\{{ }^{e} t\left(j_{\bar{s}}, p+1\right), \quad{ }^{e} t\left(j-1_{\bar{s}}, p\right),\right. \\
& \left.{ }^{e} t\left(j-2-\beta_{\bar{s}}^{-}, p-1\right)\right\} \\
& \text { ただし, } 1 \leq p \leq M, 1 \leq j \leq N, q>M \text { あるいは } \\
& \quad k<1 \text { の場合 }{ }^{e} t\left(k_{s}, q\right) \equiv 0
\end{aligned}
$$

${ }^{s} t\left(j_{s}, p\right) \equiv{ }^{e} t\left(j_{s}, p\right)-\tau_{j_{s}}{ }^{p}$ の置き換えを行ない， ${ }^{s} t(\infty$, M) から (22) 式の両辺を引き, $j_{s}=N-j+1_{s}$ であ
ることを考慮して（23）式と対照すれば，(21）式に よって決定される開始時刻が (23) 式を満足すること が明らかになる：末た，この時刻に間に合うように所

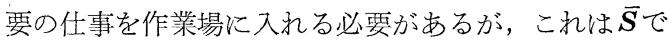
$\bar{s}$ を実行するときの可能な最早洔刻に行な壳ば良い。

(21) 式で開始時刻を決定すると $D_{s}^{-p}=D_{s}^{p}$ となる. したがって P1 $(\boldsymbol{S}, \boldsymbol{\alpha})$ の解集合 $\left\{s^{*}\right\}$ と逆順序のスケ ジュールの集合 $\left\{\bar{s}^{*}\right\}$ は常に $\mathrm{P} 1(\overline{\boldsymbol{S}}, \bar{\alpha})$ の解すべての 集合となる。 $\left\{\bar{s}^{*}\right\}$ に含まれない解 $\bar{s}^{\prime}$ があるとすると 上と裏返しの推論により， $\left\{s^{*}\right\}$ が原問題のすべての 解を含んでいるといら仮定に矛盾する。したがって次 の定理を得る.

【定理 7】 $\mathrm{P} 1(\boldsymbol{S}, \boldsymbol{\alpha})$ の解集合を $\left\{s^{*}\right\}$ とするとき， $s^{*}$ 之逆順序のスケジュールの集合 $\left\{\bar{s}^{*}\right\}$ は $\mathrm{P} 1(\overline{\boldsymbol{S}}, \overline{\boldsymbol{\alpha}})$ の解集合となる。

次に P2' $\left(\boldsymbol{S}_{\mathrm{I}}(M),[0,0, \cdots, 0,1]\right)$ とその逆順序問 題 $\mathrm{P} 2^{\prime}\left(\overline{\boldsymbol{S}}_{\mathrm{I}}(M),[0,0, \cdots, 0,1]\right)$ の関係を論ずる.ダ ッシュは $s^{1}=s^{2}=\cdots=s^{M}$ なるスケジュールの中で最 適なものを求める問題であることを意味するものとす る. $S_{\text {I }}$ では一般に， $s^{1}=s^{2}, s^{M-1}=s^{M}$ とできること が前述の Johnson-Roy の定理で示されており,さら に $\boldsymbol{S}_{\mathrm{I}}$ に関してはこの制約を課した問題が一般には考 えられているので, 以下ではこの問題を考察する.

あるスケジュール $s$ (ただし $\left.s^{1}=s^{2}=\cdots=s^{M}\right)$ を $S_{\mathrm{I}}$ で実行するとき $I^{M}$ は次式で与えられる.

$$
I^{M} \equiv \sum_{j=1}^{M} I_{j_{s}}{ }^{M}=\max _{0 \leq u_{2} \leq \cdots \leq u_{M} \leq N}\left\{\sum_{q=2}^{M} K_{u q}{ }^{q}(s)\right\} \quad(24)^{* 3}
$$

ただし，

$$
K_{u q}{ }^{q}(s) \begin{cases}\sum_{j=1}^{u_{\sigma}} \tau_{j_{s}}^{q-1}-\sum_{j=0}^{u q-1} \tau_{j_{s}}^{q} & \text { for } 1 \leq u_{q} \leq N \\ \equiv 0 & \text { for } u_{q}=0\end{cases}
$$

このことは数学的帰納法により証明することができる 同様にして，s と逆順序のスケジュール $\bar{s}$ を $\overline{S_{\mathrm{I}}}$ てで害 行すると,

$$
\begin{aligned}
& I^{1} \equiv \sum_{j=1}^{N} I_{j s}^{-1}=\max _{0 \leq w M-1 \leq \cdots \leq w_{1} \leq N}\left\{\sum_{q=1}^{M-1} K_{w q}{ }^{q}(\bar{s})\right\} \\
& \text { ただし, } K_{w q}^{q}(\bar{s}) \\
& \begin{cases}\equiv \sum_{j=1}^{v^{\prime} q} \tau_{j \bar{s}}^{q+1}-\sum_{j=1}^{w q-1} \tau_{j s}^{q}-\tau_{0}^{M-q+1} & \text { for } 1 \leq w_{q} \leq N \\
\equiv 0 & \text { for } w_{q}=0\end{cases}
\end{aligned}
$$

*3 この式は $0 \leq u_{2} \leq \cdots \leq u_{M} \leq N$ を満足する $M-1$ 個の 整数 $u_{2}, u_{3}, \cdots, u_{M}$ を適当に定めたときに得られる， $\sum_{q=2}^{M} K_{u} q^{q}(s)$ の最大値を $I^{M}$ とすることを意味する. 
さて, $\sum_{j=0}^{N} \tau_{j_{s}}{ }^{M}-\sum_{j=1}^{N} \tau_{j_{s}}{ }^{1}-\tau_{0}{ }^{M} \equiv A$ (一定) $\sum^{M-1} \sum_{q=2}^{M}\left(-\sum_{j=0}^{N}\right.$ $\left.\tau_{j s}{ }^{q}+\sum_{j=0}^{N} \tau_{j s^{q}}\right) \equiv 0$ 老加光て $u_{2}, u_{3}, \cdots, u_{M}\left(1 \leq u_{2} \leq \cdots\right.$ $\left.\leq u_{M} \leq N\right)$ で分割して適当に変形すると，

$$
\begin{aligned}
& \left\{\left(\sum_{j=u_{M}}^{N} \tau_{j_{s}}{ }^{M}-\sum_{j=u_{M}+1}^{N} \tau_{j_{s}}{ }^{M-1}-\tau_{0}{ }^{M-1}\right)\right. \\
& \quad+\left(\sum_{j=u_{M-1}}^{N} \tau_{j_{s}}{ }^{M-1}-\sum_{j=u_{M-1}+1}^{N} \tau_{j_{s}}{ }^{M-2}-\tau_{0}{ }^{M-2}\right)+ \\
& \left.\quad \cdots+\left(\sum_{j=u_{2}}^{N} \tau_{j_{s}}{ }^{2}-\sum_{j=u_{2}+1}^{N} \tau_{j_{s}}{ }^{1}-\tau_{0}{ }^{M}\right)\right\}-\sum_{q=2}^{M} K_{u q}{ }^{q}(s) \equiv A
\end{aligned}
$$

左辺第 1 項の $\tau_{0}{ }^{M-q+1}$ 之 $\tau_{0}^{q}(2 \leq q \leq M-1)$ を入れ 換え， $\sum_{j=u_{q}}^{N} \tau_{j_{s}}^{q}=\sum_{j=1}^{N-u q+1} \tau_{j s}^{-q}$ であることを利用し， $N$ $-u_{q}+1=w_{q-1}$ と和くと次式を得る.

$$
\begin{aligned}
& \sum_{q=1}^{M-1} K_{w q}{ }^{q}(\bar{s}) \equiv A+\sum_{q=2}^{M} K_{u q}{ }^{q}(s) \\
& \left(\text { ただし, } \begin{array}{l}
1 \leq u_{2} \leq \cdots \leq u_{M} \leq N \\
w_{q-1}=N-u_{q}+1
\end{array}\right)
\end{aligned}
$$

(24) 式の右辺の最大值が $u_{m-1}=\cdots=u_{3}=u_{2}=0$, $u_{m} \geqq 1(3 \leqq m \leqq M)$ でのみ実現されるときは (30) 式 が成立しなければならず，（26）式にも同様のことが いえる。

$$
\begin{aligned}
& \max _{0 \leq u_{2} \leq \cdots \leq u_{m-1} \leq u_{m}}\left\{\sum_{q=2}^{m-1} K_{u q} q(s)\right\}<0 \\
& \left(\text { ただし, } \sum_{j=2}^{m-1} u_{j} \neq 0\right)
\end{aligned}
$$

原問題の解 $s *$ につい,

$$
\begin{aligned}
\tau_{1 S^{*}}{ }^{p} & \geqq \tau_{0}{ }^{p+1} \quad \text { 拉よび } \quad \tau_{N_{S^{*}}{ }^{M-p+1}} \geqq \tau_{0}^{p+1} \\
& (1 \leq p \leq M-1)
\end{aligned}
$$

が成立すれば，(30) 式および (26) 式に対する同様の 式が成立しないので，(24)，(26）両式の右辺の最大值 は $u_{2} \geqq 1, w_{M-1} \geqq 1$ でおの沶の実現される:このとき (29）式の両辺で $\max$ をとると,

$$
\begin{aligned}
& \operatorname{ma}_{1 \leq w_{M-1} \leq \cdots \leq w_{1} \leq N}\left\{\sum_{q=1}^{M-1} K_{w_{q}} q\left(\bar{s}^{*}\right)\right\} \\
& \equiv A+\max _{1 \leq u_{2} \leq \cdots \leq u_{M} \leq N}\left\{\sum_{q=2}^{M} K_{u q}{ }^{q}\left(s^{*}\right)\right\} \\
& =\min _{s}\left[A+\max _{1 \leq u_{2} \leq \cdots \leq u_{M} \leq N}\left\{\sum_{q=\mathcal{Z}}^{M} K_{u q}^{q}(s)\right\}\right]
\end{aligned}
$$

乙たがって， $\bar{s}^{*}$ は逆順序問題の解となる．特に（33） 式が成立するときには（31）式が常に成立するから， 原問題の解と逆順序のスケジュールはすべて, 逆順序 問題の解となる.

$$
\min _{1 \leq j \leq N}\left(\tau_{j}^{p}, \tau_{j}^{M-p+1}\right) \geqq \tau_{0}^{p+1} \quad(1 \leq p \leq M-1)
$$

【定理 8】 $\mathrm{P} 2^{\prime}\left(\boldsymbol{S}_{\mathrm{I}},[0, \cdots, 0,1]\right)$ の解 $s^{*}$ 之逆順の スケジュール $\bar{s}^{*} は ， s^{*}$ について (31) 式が成立する
ときその逆順序問題の解となる。特汒，(33) 式が成 立する問題では原問題の解と逆順序のスケジュールは 常に逆順序問題の解となる.

$M=2$ の場合には (34) 式が成立すれば 問題の解となる.

$$
\min \left(\tau_{j \bar{s}^{-2}}, \tau_{j+1 s^{-1}}\right) \leqq \min \left(\tau_{j s}^{-1}, \tau_{j+1 s^{-2}}\right)
$$

$j_{s}=N-j+1_{s}$ に注意すれば，(10) 式を満たすスケジ ュールと逆順序のスケジュールが（34）式を満たすこ とは明らかである。したがうて次のことがい党る。

【定理 9】 $\mathrm{P} 2\left(\boldsymbol{S}_{\mathrm{I}}(2), \boldsymbol{\alpha}\right)$ の Johnson の十分条件 （10）学満たす解と逆順序のスケジュールは P $2\left(\overline{S_{\mathrm{I}}}(2)\right.$, 文) の解である.

$\mathrm{P} 2(\boldsymbol{S},[0, \cdots 0,1])$ と $\mathrm{P} 2(\overline{\boldsymbol{S}},[0, \cdots, 0,1])$ の関係に ついては, $T_{0}=\bar{T}_{0}=0$ の場合には両者の解が互いに 逆順序であることを定理 7 を用いて容易に示すことが できる。

\section{6. 結果のま亡めと考察}

2.ではショップの概念を明確にし, 溜り場容量, 初期条件, 終了条件の諸点で一般化した問題を定義し た.これによって, 従来の研究対象の主なものの特殊 性が明らかになるとともに，前後のスケジュールとの 調整を行ならことも可能になり(初期条件・終了条件), さらに溜り場容量の異なるフロー・ショップ間の比較 を行うための基礎が与えられた。

3.〜5. では一般化した問題を種々の面から解析し て次のような結果を得た。

（1）目的関数の下界に関する定理（定理 1).

(2) Johnson-Roy の定理が一般のフロー・ショ ップに数いても成立すること（定理 2).

（3） $T_{0}$ と $T_{\infty}$ がともに与えられた任意のフロー ・ショップでの問題の解集合は, 目的関数の重み $\boldsymbol{\alpha}$ 変化してb不変である(定理 3 ).

（4）Johnson の $S_{\mathrm{I}}$ での 2 段問題に対する解法は 任意の初期条件, 終了条件に対して有効であることの 証明（定理 4）とこの定理の仕事数が增減する場合へ の応用 (系 4-1，2）. この方法で得られる解と逆の順 序のスケジュールは逆順序問題の解となること（定理 $9)$.

（5） $S_{\text {II }}$ での 2 段問題を巡回七ールスマン問題と 同值になるように変形できることを保証する定理（定 理 5$)$.

（6）任意のフロー・ショップでの $T_{0}$ と $T_{\infty}$ が ともに与えられた問題の解はその逆順序問題の解と逆 の順序であり, 両者の目的関数值は等しいこと（定理 $6,7)$. 
（7）原問題と逆順序問題の解が互いに逆の順序で あるといら関係は, 終了条件自由のときは一般には成 立せず，ある条件下でのみ成立する（定理 8).

(2),（4）は従来の研究結果が一般化した問題に ついても成立することを示したものであり，他のもの は新佂証明したものである。おた，(24)式は Johnson の式1) の一般化である.フロー・ショップはジョブ・ ショップの中で最も扱い易いシステムであるが，一般 的な解法は求められていない，現在のところ Branch and Bound 法が不十分ながら適当であるとされてい る。これを適用するさいには，性質（1）から目的関 数の下界は原問題をいくつかの 2 段問題に分割するこ とによって計算でき, そのさい, 性質（4）は JobBased-Bound の従来(6)より高精度な推定を可能にする。 性質 $(5)$ は $S_{\text {II }}$ での問題を巡回セールスマン問題の 解法を利用して解く方向を示唆して扮り, 著者らの計 算実験ではかなり有望な結果が出ている.

逆順序問題に関しては, P2 $\left(\boldsymbol{S}_{\mathrm{I}},[0,0, \cdots, 0,1]\right)$ の $T_{0}=[0,0, \cdots, 0]$ の場合には原問題之逆順序問題の間 に対称性（最適解が互いに逆の順序であること）があ り，原問題を解くのに有益であることが知られていた が6)，これは定理 8 の式 (33) が成立する場合であり 5. の最後に述べた一般の $S$ のP2-問題とその逆順序 問題の関係の特殊な場合でもある. 完全に対称性があ るのは終了条件が与兄られた場合である（定理 7 ）. フロー・ショップの流れの向きを逆にしても工程上不 都合がない場合は（a）終了条件自由のときは原問題 の解がわかれば，(32）式を用いて簡単にどちらの向 きを採るべきかを決定でき，（b）終了条件が与兄ら れる場合はどちらを採っても同じであるなど，この対 称性はシステム設計のさいにも有益である.

\section{7. 結言}

著者らはジョブ・ショップ・システムを規定するに 当たり溜り場の概念を，また問題設定に当たっては初 期条件, 終了条件を導入し, さらに目的関数としてシ ョップの稼動率も評価できるより一般的な評価を考克 るなど実際的な場合を多く包含できる形問題を規定 しこのようなスケジューリング問題の重要な性質を
いくつか明らかにすることができた。

著者らはまた，フロー・ショップ問題を明確に記述 するとさいして、ショップの構成に注目したフロー・ ショップの定義と問題簡単化のための制約とを分離し て考察したが，このような立場をとって初めてシステ ム設計にスケジューリング理論を利用することが可能 になり，さらに定理 5 のように種々のスケジニーリン グ問題相互の関連を明確にできると考兄る.

本論文で报った問題は種々の抽象化，一般化を行な ったものであるから，現場で起こる個々の問題に対し て，ここで行なった解析をそのまま通用できない場合 が多いと思われる。しかし，ラインで多種少量生産を 行父らときにはライン設計の指針として，あるいは工 場のシステム化などのさいに目实をつける基準として， 本論文で述べた理想化システムの解析が必ず有益なも のであると信ずる.

本論文では解析の結果のみを述べ，最適スケジュー ルを求める実際的手法については注とんど論及しなか ったけれども，上述の諸結果を利用すれば最適スケジ ニールを求めるかなり効率良いアルゴリズムを構成す ることができる。この点については続報で発表する予 定である.

\section{参考 文 献}

1) S. M. Johnson : Optimal Two and Three Stage Production Schedules and Setup Times Included, Naval Res. Log. Quart. 1, 61/68 (1954)

2) B. Gittler and G. L. Thompson : Algorithms for Solving Production-Scheduling Problems, Opns. Res. 8, 487/503 (1960)

3) 原: Cyclic Sequencing とその近似解法, 経営科学, 10-3, 141/147 (1967)

4) Z. A. Lomnicki : A "Branch-and-Bound" Algorithm for the Exact Solution of the Three Machine Scheduling Problem, Opnl. Res. Quart., 16, 89/ 100 (1965)

5) B. Roy: Cheminement et Connexité dans les Graphs-Applications aux Problèmes d'Ordonnancement, METRA, Série Speciale No.1, Société d'Economie et de Mathématiques Appliquées, Paris

6) G. B. McMahon and P. G. Burton : Flow-Shop Scheduling with the Branch-and-Bound Method, Opns. Res. 15, 473/481 (1967) 